\title{
Administrasi Sarana dan Prasarana Pendidikan
}

\author{
Nadya Olivia Perrina \\ Universitas Negeri Padang \\ Indonesia \\ nadyaolivia2509.nogmail.com
}

\begin{abstract}
Abstrak-this article discusses the administration of infrastructure. Educational facilities are equipment and equipment that are directly used and support the educational process, especially the teaching and learning process. For example: buildings, classrooms, tables, chairs. Educational infrastructure is a facility that indirectly supports the course of the education process, but can be utilized for the learning process. For example: school parks for teaching biology.
\end{abstract}

Keywords-Administrasi sarana dan prasarana, gedung, alat perabotan sekolah.

\section{PENDAHULUAN}

Dalam dunia pendidikan, terdapat beberapa komponen pendidikan yang sangatlah berperan sebagai penunjang kegiatan pembelajaran baik secara langsung maupun tidak langsung. Salah satu komponen terpenting adalah sarana dan prasarana pendidikan.

Administrasi sarana dan prasarana pendidikan merupakan hal yang sangat menunjang bagi tercapainya tujuan dari pendidikan. Proses belajar mengajar akan semakin sukses bila sarana dan prasarana pendidikan memadai. Untuk itu sarana dan prasarana pendidikan harus selalu lengkapi. Pemerintah harus selalu berupaya untuk secara terus menerus melengkapi sarana dan prasarana pendidikan bagi seluruh jenjang dan tingkat pendidikan.

Dalam makalah ini akan dibahas mengenai administrasi sarana dan prasarana pendidikan agar proses pendidikan dapat berjalan dengan efektif dan efisien.

\section{Metode Penelitian}

Artikel ilmiah sesuai kaidahnya disusun denga sistimatis. Pada artikel ini penulis menggunakan metode studi litelatur yaitu mengumpulkan dan merangkum materi yang bersumber dari buku, jurnal, dan sumber lainnya yang terkait dengan ilmu adminstrasi pendidikan.

\section{KAJIAN TEORI DAN PEMBAHASAN}

\section{A. Pengertian Administrasi Sarana dan Prasarana}

Salah satu aspek yang mendapat perhatian utama dari setiap administrator pendidikan adalah mengenai sarana dan prasarana pendidikan. Secara etimologis (bahasa) sarana berarti alat langsung untuk mencapai tujuan pendidikan. Sarana pendidikan umumnya mencakup semua peralatan dan perlengkapan yang secara langsung dipergunakan dan menunjang dalam proses pendidikan harus sesuai dengan proses pembelajarannya seperti gedung, ruang belajar atau kelas, alat-alat atau media pendidikan, meja, kursi,laboratorium dan sebagainya.

Sedangkan yang dimaksud dengan prasarana adalah fasilitas yang secara tidak langsung menunjang jalannya proses pendidikan, seperti halaman yang bagus untuk melakukan pembelajaran, kebun atau taman sekolah yang enak di pandang, jalan menuju ke sekolah mudah, tata tertib sekolah, dan sebagainya.

Dengan demikian dapat di tarik suatau kesimpulan bahwa Administrasi sarana dan prasarana pendidikan itu adalah semua komponen yang secara langsung maupun tidak langsung menunjang jalannya proses pendidikan untuk mencapai tujuan dalam pendidikan itu sendiri.

Sedangkan menurut rumusan Tim Penyusun Pedoman Pembukuan Media Pendidikan Departemen Pendidikan Dan Kebudayaan, yang dimaksud dengan "sarana pendidikan adalah semua fasilitas yang diperlukan dalam proses belajar mengajar, baik yang bergerak maupun yang tidak bergerak agar pencapaian tujuan pendidikan dan berjalan dengan lancar, teratur, efektifdan efesien.Menurut keputusan menteri P dan K No 079/ 1975, sarana pendidikan terdiri dari 3 kelompok besar yaitu :

a. Bangunan dan perabot sekolah

b. Alat pelajaran yang terdiri dari pembukuan, alat-alat peraga dan laboratorium.

c. Media pendidikan yang dapat di kelompokkan menjadi audiovisual yang menggunakan alat penampil dan media yang tidak menggunaakan alat penampil.

Secara micro (sempit) kepala sekolah lah yang bertanggung jawab atas pengadaan sarana dan prasarana pendidikan yang di perlukan di sebuah sekolah.Sedangkan administrasi sarana dan prasarana itu sendiri mempunyai peranan yang sangat penting bagi terlaksananya proses pembelajaran di sekolaah serta menunjang tercapainya tujuan pendidikan di sebuah sekolah baik tujuan secara khusus maupun tujuan secara umum.

Terdapat pula beberapa pemahaman mengenai administrasi sarana dan prasarana di antaranya adalah :

a. Berdasarkan konsepsi lama dan modern 
Menurut konsepsi lama administrasi sarana dan prasarana itu di artikan sebagai sebuah sistem yang mengatur ketertiban peralatan yang ada di sekolah . Menurut konsepsi modern administrasi sarana dan prasarana itu adalah suatu proses seleksi dalam penggunaan sarana dan prasarana yang ada di sekolah. Guru menurut konsepsi lama bertugas untuk mengatur ketertiban penggunaan sarana sekolah, menurut konsepsi modern guru bertugas sebagai administrator dan bertanggung jawab kepada kepala sekolah.

\section{b. Berdasarkan pandangan pendekatan operasional tertentu}

1. Seperangkat kegiatan dalam mempertahankan ketertiban penggunaan sarana dan prasarana di sekolah melalui penggunaan di siplin (pendekatan otoriter )

2. Seperangkat kegiatan untuk mempertahankan ketertiban sarana dan prasarana sekolah dengan melalui pendekatan intimidasi

3. Seperangkat kegiatan untuk memaksimalkan penggunaan sarana dan prasarana sekolah dalam proses pembelajaran (pendekatan permisif)

4. Seperangkat kegiatan untuk mengefektifkan penggunaan sarana dan prasarana sekolah sesuai dengan program pembelajaran (pendekatan intruksional)

5. Seperangkat kegiatan untuk mengembangkan sarana dan prasarana sekolah

6. Seperangkat kegiatan untuk mempertahankan keutuhan dan keamanan dari sarana dan prasarana yang ada di sekolah.

Pengertian lain dari administrasi sarana dan prasarana adalah suatu usaha yang di arahkan untuk mewujudkan suasana belajar mengajar yang efektif dan menyenangkan serta dapat memotivasi siswa untuk belajar dengan baik sesuai dengan kemampuan dan kelengkapan sarana yang ada.

Dengan demikian adminitrasi sarana dan prasarana itu merupakan usaha untuk mengupayakan sarana dan alat peraga yang di butuhkan pada proses pembelajaran demi lancarnya dan tercapainya tujuan pendidikan .

\section{B. Proses Administrasi Sarana dan Prasarana}

Sarana dan prasarana pendidikan pada dasarnya dapat dikelompokan dalam empat kelompok, yaitu tanah, bangunan, perlengkapan, dan perabot sekolah. Agar semua fasilitas tersebut memberikan kontribusi yang berarti pada jalannya proses pendidikan, hendaknya dikelola dengan dengan baik.
Pengelolaan yang dimaksud meliputi:

1. Perencanaan

2. Pengadaan

3. Inventarisasi

4. Penyaluran

5. Pemanfaatan dan pemeliharaan

6. Penghapusan

7. Pengawasan

\section{Perencanaan}

\section{- Perencanaan Kebutuhan, Pengadaan dan Pengembangan Sarana dan Prasarana Pendidikan}

Perencanaan sarana dan prasarana pendididkan merupakan pekerjaan yang komplek, karena harus terintegrasi dengan rencana pembangunan baik nasional, regional maupun lokal, prencanaan ini merupakan sistem perencanaan terpadu dengan perencanaan pembangunan tersebut. perencanaan kebutuhan sarana dan prasarana pendidikan tergantung pada jenis program pendidikan dan tujuan yang ditetapkan.

Program pendidikan yang berorientasi pada pemenuhan kebutuhan tenaga kerja akan berbeda dengan program pendidikan yang berorientasi pada pemerataan kesempatan belajar, dalam hal sarana dan prasarananya, karena itu dalam perencanaan kebutuhan tersebut tersebut perlu dikaji sstem internal pendidikan dan aspek eksternalnya seperti masalah demographi, ekonomi kebijakan-kebijakan yang ada. Kegagalan dalam tahap perencanaan ini akan merupakan pemborosan. Prinsip prinsip umum dalam perencanaan seperti komprehensif, obyektif, fleksibel dan interdisiplin perlu diperhatikan.

\section{- Perencanaan pengadaan tanah untuk gedung atau bangunan sekolah}

Sekolah tidak bisa dibangun disembarang tempat. Menurut Frabk W.Banghart sekolah hendaknya dibangun pada tempat atau lokasi yang baik yang dapat memberikan pengaruh positif pada perkembangan siswa. Selain itu Soerjani (1988:135) mengemukakan: "Dalam mensirikan gedung sekolah, perlu diperhatikan tentang letak sekolah dan lingkungannya. Letak dan lingkungan sekolah adalah salah satu komponen yang dapat menunjang atau menghambat usaha meningkatkan ketahanan sekolah".

Dengan memperhatikan pendapat diatas maka tempat atau letak tanah untuk bangunan sekolah harus benar-benar memperhatikan, dan mempertimbangkan keadaan lingkungan sekolah, kebutuhan murid-murid sekolah, serta kurikulum sekolah itu sendiri. 
Syarat-syarat yang harus diperhatikan menurut J.Mamusung antara lain:

1. Mudah dicapai dengan berjalan kaki ataupun berkendaraan

2. Terletak disuatu lingkungan yang banyak hubungan dengan kepentingan pendidikan (sekolah)

3. Cukup luas, bentuk maupun tofogafinya akan memenuhi kebutuhan

4. Mudah menjadi kering jika digenangi air, bebas dari pembusukan dan tidak merupakan tanah yang konstruksinya adalah hasil buatan / timbangan / urugan

5. Tanahnya yang subur, sehingga mudah ditanami dan indah pemandangan alam sekitarnya

6. Cukup air ataupun mudah dan tidak tinggi biayanya jika harus menggali sumur ataupun memasang pipapipa perairan

7. Terdapat air yang bersih dan berkualitas

8. Memperoleh sinar matahari yang cukup selama waktu sekolah berlangsung, sehingga kelancaran dan kesehatan terjamin

9. Tidak terletak di tepi jalan/persimpangan jalan yang ramai dan berbahaya dan tidak berdekatan dengan rumah sakit, kuburan, pabrik-pabrik yang membisingkan, pasar dan tempat-tempat lain yang dapat memberikan pengaruh-pengaruh negatif

10. Harganya tidak terlalu mahal (murah)

Dengan memperhatikan syarat-syarat diatas tidak semua tanah dapat dijadikan untuk tempat pendidikan. Untuk sebelum tanah itu dibeli perlu terlebih dahulu adanya perencanaan. Dalam pengadaan tanah yang meliputi:

1. Membuat rencana pengdaan tanah, luas dan lokasi sesuai dengan kebutuhan

2. Melakukan survey, dilakukan untuk menentukan lokasi tujuan dan perencanaan tata kota

3. Melakukan survey untuk melihat kondisi fisik lainnya, misalnya: jalan, listrik, transportasi, air dan sebagianya

4. Harga tanah, dilakukan untuk bahan pengajuan rencana anggaran

\section{- Perencanaan Pengadaan Bangunan Gedung Sekolah}

Sekolah merupakan lembaga tempat mendidik anak agar menjadi warga Negara yang kreatif dan produktif. Untuk itu menunut adanya gedung yang memadai sehingga pada tiap murid ada perasaan bangga dan bersekolah selama dididik dalam gedung tersebut. selain itu untuk menumbuhkan penghormatan murid terhadap lembaga tempat ia dididik, seyogyanya sekolah didirikan dalam lingkungan yang cukup terhormat.
Ada beberapa syarat yang harus dipenuhi oleh suatu bangunan yang ideal, J.Mumusung (1981:16) mengemukakan sebagai berikut:

1. Memenuhi kebutuhan dan syarat pedagogis

2. Ukuran dan bentuk ruangan disesuaikan dengan kebutuhan

3. Datangnya dan Masuknya sinar matahri harus diperhatikan, yaitu dari arah sebelah kiri

4. Tinggi rendahnya tembok, letak jendela dan kusen disesuaikan dengan kondisi anak-anak

5. Pengunaan warna yang cocok

6. Aman, artinya material dan kontruksi bangunannya benar-benar dapat dipertanggungjawabkan baik kekuatan/kekokohan bangunan itu sendiri, maupun pengaruh erosi, angin, getaran, petir dan pohon yang berbahaya

7. Menurut syarat kesehatan, sinar matahari cukup bagi setiap ruanganmemungkinkan adanya pergantian udara yang segar selalu

8. Menyenangkan untuk melakukan kegiatan-kegiatan pendidikan dan tak saling mengganggu

9. Dapat memungkinkan untuk memperluas tanpa memakan biaya lagi yang besar

10. Fleksibel, artinya melihat kebutuhan hari depannya dan dapat pula dirubah-rubah setiap saat diperlukan

11. Memenuhi syarat keindahan

12. Ekonomis

Agar syarat-syarat diatas dapat terpenuhi maka hendaknya sebelum gedung itu dibangun perlu dibuat perencanaan terlebih dahulu, dengan langkah-langkah sebagai berikut:

1. Mengadakan survey untuk mengetahui kesesuaian antara gedung yang akan dibangun dengan kebutuhan sekolah, baik tingkat maupun jenisnya, serta ukurannya

2. Menentukan ruang dan perlengkapan dalam arti kualitas bahan, jumlah ruangan, luas ruangan, banyaknya perabot, kualitas dan ukurannya

3. Mengadakan survey untuk menentukan lokasi

4. Menyusun anggaran biaya yang disesuaikan dengan harga standar yang berlaku di daerah bersangkutan

\section{- Perencanaan Pembangunan Bangunan Sekolah}

Seperti halnya sarana lainnya, pembangunan gedung sekolah harus direncanakan terlebih dahulu. Sesuai dengan fungsinya gedung sekolah tersebut merupakan tempat anakanak belajar, sudah sepantasnya gedung sekolah yang dibangun harus cukup cahaya masuk agar ruangan menjadi terang, cukup ventilasi, gedung tersebut mempunyai kualitas yang baik, bagi dari segi konstruksi maupun dari segi keindahannya dan juga memperhatikan segi kesehatan. 
Sebagai sarana atau tempat yang akan dibangun untuk kegiatan belajar mengajar, gedung sekolah yang akan dibangun selain harus memperhatikan segi kualitas juga memeperhatikan kurikulum pendidikan sekolah, untuk itu maka dalam membangun gedung sekolah menuntut adanya suatu perencanaan dengan prosedur sebagai berikut:

1. Melakukan survey berkenaan dengan bangunan sekolah yang akan dibangun, yang meliputi :

a. Fungsi bangunan

b. Jumlah pemakai, baik pegawai, guru dan murid

c. Program pendidikan atau kurikulum sekolah

d. Jenis dan jumlah alat-alat atau perabot yang akan ditempatkan pada gedung sekolah tersebut.

2. Mengadakan perhitungan luas bangunan yang disesuaikan dengan kebutuhan dan disusun berdasarkan hasil survey tersebut.

3. Menyusun anggaran biaya yang dibutuhkan untuk pembangunan gedung tersebut. yang disusun dengan harga standar yang berlaku pada daerah tempat tersebut akan dibangun.

Dalam perencanaan pembangunan gedung sekolah ini juga harus drencanakan mengenai keadaan gedung sekolah itu sendiri, untuk itu maka perlu dibuat gambar kerja dengan maksud sebagai pedoman dalam pelaksanaan pembangunan gedung. Dalam penyusunannya, hendaknya berpedoman pada standar yang ditentukan pada buku pedoman departemen yang telah ditetapkan oleh departemen.

\section{- Perencanaan Pengadaan Perabot dan Perlengkapan Pendidikan}

Dengan perabot dan perlengkapan yang asal saja, sudah barang tentu proses pendidikan berjalan kurang efektif yang pada gilirannya lulusannya yang dihasilkan mempunyai atau kecakapan yang tidak sesuai dengan harapan.

Kegiatan pendidikan merupakan usaha yang terencana dan mempunyai tujuan yang jelas, kerana itu hendaknya perabot pendidikan direncanakan sesuai dengan dengan kebutuhan anak yang beraneka ragam sifat dan keperluannya, baik secara individual ataupun kelompok dan kurikulum atau program pendidikan yang akan dilakukan oleh sekolah. Ini berati adanya keharusan untuk memilih dan memiliki perabot dan perlengkapan yang sesuai dengan umur, minat serta tarap perkembangan fisik maupun phsyshis dari setiap murid dan kurikulum sekolah yang bersangkutan.

Dilandasi pemikiran diatas maka perabot dan perlengkapan yang dibuat harus memenuhi syarat (perabot sekolah) sebagai berikut:

a. Ukuran fisik pemakai/murid agar pemakaiannya fungsional dan efektif. b. Bentuk dasar yang memenuhi syarat-syarat sebagai berikut:

a) Sesuai dengan aktivitas murid dalam PBM

b) Kuat, mudah memeliharanya, dan mudah dibersihkan

c) Mempunyai pola dasar yang sederhana

d) Mudah dan ringan untuk disusun/disimpan

e) Flexible sehingga mudah diguakan dan dapat pula berdiri sendiri

f) Konstruksi hendaknya:

1. Kuat dan tahan lama

2. Mudah dikerjakan secara masal

3. Tidak tergantung keamanan pemakainya

4. Bahan yang mudah didapat dipasaran dan disesuaikan dengan keadaan setempat

5. Syarat-syarat untuk perlengkapan sekolah

Agar perlengkapan yang digunakan itu benar-benar tepat guna, maka baik jenis, bentuk, serta warna hendaknya benar-benar disesuaikan dengan kebutuhan dan kepentingan kegiatan anak didik/siswa.

Ini berarti adanya keharusan untuk memilih dan memiliki alat-alat yang sesuai dan disesuaikan dengan umur, minat, serta taraf perkembangan fisik maupun psikis anak didik. Untuk itu diperlukan:

1. Keadaan baku/material harus kuat, tetapi ringan, tidak membahayakan keselematan anak didik

2. Konstruksi harus sedemikian rupa, sehingga sesuai dengan kondisi peserta didik

3. Dipilih dan direncanakan dengan teliti dan baik serta benar-benar disesuaikan usia, minat, tarap perkembangan anak didik

4. Pengadaan pengaturan harus sedemikian rupa sehingga benar-benar berfungsi bagi penanaman, pemupukan, serta pembinan hal-hal yang berguna bagi perkembangan anak.

Dalam perencanaan perlengkapan dan perabot sekolah. Depdiknas mengelompokannya menjadi barangbarang yang habis dipakai barang-barang yang tak habis dipakai. Untuk perencanaannya adalah sebagai berikut (Depdiknas, 1980):

1. Barang yang habis dipakai, direncanakan dengan urutan sebagai berikut:

a. Menyusun daftar perlengkapan yang disesuaikan dengan kebutuhan dari rencana kegiatan sekolah tiap bulan

b. Menyusun perkiraan biaya yang diperlukan untuk pengadaan barang tersebut tiap bulan

c. Menyusun rencana pengadaan barang tersebut menjadi rencana triwulan dan kemudian menjadi rencana tahunan. 
2. Barang tak habis pakai, direncanakan dengan urutan sebagai berikut:

a. Menganalisis dan menyusun keperluan perlengkapan sesuai dengan rencana kegiatan sekolah serta memperhatikan perlengkapan yang direncanakan dengan memperhatikan perlengkapan yang masih ada dan masih dapat dipakai

b. Memperkirakan biaya perlengkapan yang direncanakan dengan memperhatikan standar yang telah dilakuakan

c. Menetapkan skala prioritas menurut dan yang tersedia, urgensi kebutuhan dan menyusun rencana pengadaan tahunan.

\section{Pengadaan}

Untuk pengadaan sarana dan prasarana pendidikan dapat dilakukan dengan berbagai cara. Misalnya untuk pengadaan tanah bisa dilakuakn dengan cara membeli, menerima hibah, menerima hak pakai, menukar dan sebgainya. Dalam pengadaan gedung/bangunan dapat dilakukan dengan cara membangun baru, memebeli, menyewa, menerima hibah, atau menukar bangunan. Untuk pengadaan perlengkapan atau perabot sekolah dapat dilkukan dengan jalan membeli. Perabot yang akan dibeli dapat berbentuk yang sudah jadi, atau yang belum jadi. Dalam pengadaan perlengkapan ini juga dapat dilakukan dengan jalan membuat sendiri atau menerima bantuan dari instansi pemerintah dari luar Departemen Pendidikan Nasional, badan-badan swasta, masyarakat, perorangan dan sebagainya.

Dalam pengadaan sarana diatas selain perlu diperhatikan segi kualitas dan kuantitas, juga diperhatikan prosedur atau dasr hukum yang berlaku, sehingga sarana yang sudah ada tidak menimbulkan masalah dikemudian hari. Misalnya dalam pembelian tanah perlu jelas surat-surat tanah yang akan dibeli, demikian juga dengan akte jual belinya, demikian juga kalau menerima hibah dari pihak lain supaya ada dasr hukumnya, sebaiknya dalam pelaksanaanya dilakukan dengan Akte Notaris Pejabat pembuat akte tanah setempat. Sedangkan untuk yang sifatnya hak pakai, seperti lahan hendaknya disertai dokumen serah terima dari pihak yang memberikan hak pakai. Untuk sarana yang diperoleh melalui siswa perlu juga dibuat surat perjanjian (kontrak) antar pihak penyewa dan pihak yang menyewakan dan sebagainya.

Pada setiap sekolah seyogyanya ada petugas khusus yang melaksanakan tugas berkaitan dengan urusan perlengkapan. Kegiatannya meliputi, menerima, menyimpan dan mengeluarkan barang dari tempat penyimpanan barang/gudang. Barang atau sarana pendidikan yang ada pada setiap sekolah banyak macamnya. Dalam menyimpan barangbarang tersebut hendaknya diperhatikan sifat-sifat barang tersebut.
Dalam penyimpanan barang-barang juga perlu diperhatikan tempat penyimpanan barang tersebut. gudang hendaknya ditempatkan pada lokasi yang mudah dijangkau, fasilitas pendukungnya, seperti : listrik, air, dan sebagainya. Gudang tersebut kondisnya harus baik. Untuk terjaminnya pelaksanaaan peyimpanan barang atau sarana pendidikan perlu diperhatikan hal-hal sebagai berikut:

1. Syarat-syarat pergudangan yang berlaku

2. Sifat barang yang disimpan

3. Jangka waktu penyimpanan

4. Alat-alat atau sarana lain yang diperlukan untuk penyimpanan

5. Dana atau biaya untuk pemeliharaan

6. Prosedur kerja penyimpanan yang jelas dan disesuaikan dengan sifat barang yang disimpan.

\section{Inventarisasi}

Semua srana dan prasaran sekolah hendaknya diinventarisir, melalui inventarisasi memungkinkan dapat dikethui jumlah, jenis barang, kualitas, tahun pembuatan, merek.ukuran, haraga dan sebagainya. Khususnya untuk sarana dan prasarana pendidikan yang berasal dari pemerintah (milik Negara) wajib diadakan inventarisasi secara cermat, dengan menggunakan format-format yang telah ditetapkan. Atau mencatat inventarisasinya di dalam buku Induk Barang Inventaris dan Buku Golongan Inventaris. Buku inventaris ini mencatat semua barang barang inventaris milik menurut urutan tunggal. Sedangkan buku golonganbarang inventaris mencatat barang inventaris menurut golongan barang yang telah ditentukan.

\section{Penyaluran}

Penyaluran merupakan kegiatan yang menyangkut pemindahan barang dan tanggung jawab dari instansi/pemegang yang satu kepada instansi/pemegang yang lain.Kegiatan penyaluran barang yang baik meliputi penyusunan alokasi, pengiriman barang (untuk pusat-pusat penyalur) dan penyerahan barang.

a. Penyusunan alokasi, dilakukan untuk menghindari pemborosan dalam pendistribusian barang sehingga merata dan seimbang dengan kebutuhan

b. Pengiriman barang yang dilakukan dari pusat-pusat penyalur barang

c. Penyerahan Barang, dalam penyerahan barang jangan lupa untuk mengisi daftar penyerahan barang, surat pengantar, faktur, tanda terima penyerahan barang, biaya pengiriman jika ada dan sebagainya.

\section{Pemanfaatan dan Pemeliharaan}

Sarana dan prasarana merupakan penunjang untuk keaktifan proses belajar mengajar. Barang-barang tersebut 
kondisinya tidak akan tetap, tetapi lama kelamaan akan mengarah pada kerusakan, kehancuran bahkan kepunahan. Namun agar saran dan prasarana tersebut tidak cepat rusak atau hancur diperlukan usaha pemeliharaan yang baik dari pihak pemakainya. Pemeliharaan atau maintenanace merupakan suatu kegiatan yang kontinu untuk mengusahakan agar sarana dan prasarana pendidikan yang ada tetap dalam keadaan baik dan siap untuk dipergunakan.

Pemeliharaan adalah suatu kegiatan dengan pengadaan biaya yang termasuk dalam keseluruhan anggaran persekolahan dan diperuntukan bagi kelangsungan "building", "equipment", serta "furniture", termasuk penyediaan biaya bagi kepentingan perbaikan dan pemugaran, serta penggantian. Perlunya pemeliharaan yang baik terhadap bangunan, perabot dan perlengkapan sekolah dikarenakan kerusakan sebenarnya telah dimulai semenjak hari pertama gedung, perabot dan perlengkapan itu diterima dari pihak pemborong, penjual atau pembeli sarana tersebut, kemudian disusul oleh proses kepunahan, meskipun pemeliharaan yang baik telah dilakukan terhadapa sarana tersebut selama dipergunakan. J.Mamusung telah mengelompokan, ada 5 faktor yang mengakibatkan kerusakan pada bangunan, perabot dan perlengkapan sekolah, yaitu:

1. Kerusakan dikarenakan pemakaian dan pengrusakan, baik disengaja maupun yang tidak oleh pemakai.

2. Kerusakan dikeranakan pengaruh udara, cuaca, musim, maupun keadaan lingkungan.

3. Keusangan (out of date) disebabkan moderenisasi di bidang pendidikan serta perkembangannya

4. Kerusakan karena kecelakaan atau bencana disebabkan kecerobohan dalam perencanaan, pemeliharaan, pelaksanaan, maupun penggunaan yang salah

5. Kerusakan karena timbulnya bencana alam seperti banjir gempa dan lain2

Menurut waktunya kegiatan pemeliharaan terhadap bangunan dan perlengkapan serta perabot sekolah dapat dibedakan menjadi pemeliharaan yang dilakukan setiap hari dan pemeliharaan yang dilakukan secara berkala.

\section{Penghapusan}

Barang-barang yang sudah ada di sekolah, terutama yang berasal dari pemerintah (khusus sekolah negeri) tidak akan selamanya bisa digunakanan dan dimanfaatkan untuk kepentingan pendidikan, hal ini dikarenakan rusak berat sehingga tidak bisa dipergunakan lagi, barang tersebut sudah tidak sesuai dengan kebutuhan dan keadaan, biaya pemeliharaan yang tinggi, jumlah barang tersebut berlebihan sehingga tidak bisa dimanfaatkan, dan nilai guna barang tersebut tidak perlu dimanfaatkan. Dengan keadaan seperti diatas maka barang-barang tersebut harus segera dihapus, artinya, menghapus barang-barang inventaris itu (milik
Negara) dari daftar inventaris sesuai dengan ketentuan yang berlaku. Dengan adanya penghapusan ini maka barang tersebut dibebaskan dari biaya perbaikan dan pemeliharaan, selain itu dengan adanya penghapusan ini akan meringankan beban kerja inventaris dan membebaskan tanggung jawab sekolah terhadap barang tesebut.

\section{Pengawasan}

Pengawasan adalah suatu proses dimana pimpinan ingin mengetahui apakah hasil pelaksanaan pekerjaan yang dilakukan oleh bawahannya sesuai dengan rencana, perintah, tujuan atau kebijaksanaan yang telah ditentukan. Pengawasan bukan hanyamencari kesalahan saja, tetapi juga mencari halhal yang sudahbaik untuk dikembangkan lebih lanjut.Tujuan pengawasan agar hasil pekerjaan diperoleh secara berdaya guna yaituhasil yang sesuai dan tepat dengan pengeluaran yang seminimal mungkin dan sesuai dengan rencana yang telah ditentukan.

\section{C.Tujuan dan Fungsi Administrasi Sarana dan Prasarana}

Manajemen sarana dan prasarana pendidikan bertugas mengatur dan menjaga sarana dan prasarana pendidikan agar dapat memberikan kontribusi secara optimal dan berarti pada proses pendidikan.

Manajemen sarana dan prasarana yang baik diharapkan dapat menciptakan sekolah yang bersih, rapi, indah sehingga menciptakan kondisi yang menyenangkan selain itu,administrasi sarana dan prasarana sekolah berfungsi untuk:

1) Memberi dan melengkapi fasilitas untuk segala kebutuhan yang diperlukan dalam proses belajar mengajar.

2) Memelihara agar tugas-tugas murid yang di berikan oleh guru dapat terlaksana dengan lancar dan optimal.

Adapun tujuan dari administrasi sarana dan prasarana itu adalah :

(a) Mewujudkan situasi dan kondisi sekolah yang baik sebagai lingkungan yang memungkinkan peserta didik untuk mengembangkan kemampuan semaksimal mungkin

(b) Menghilangkan berbagai hambatan yang dapat menghalangi terwujudnya interaksi dalam pembelajaran

(c) Menyediakan dan mengatur fasilitas serta perabot belajar yang mendukung dan memungkinkan siswa belajar sesuai dengan lingkungan sosial, emosional, dan intelektual siswa dalam proses pembelajaran.

(d) Membina dan membimbing siswa sesuai dengan latar belakang sosial, ekonomi, budaya serta sifat- sifat individunya. 


\section{D.Peran Guru dalam Administrasi Sarana dan Prasarana}

Guru merupakan salah satu pelaku dalam kegiatan sekolah.oleh karena itu,ia dituntut untuk mengenal tempat bekerja nya itu.pemahaman tentang apa yang terjadi disekolah akan banyak membantu mereka memperlancar tugasnya sebagai pengelola langsung proses belajar mengajar.

Bagi guru, pemahaman tentang administrasi pengembangan kurikulum akan sangat membantu dalam menerjemahkan kurikulum menjadi pengalaman belajar siswa,pemahaman tentang administrasi kesiswaan akan sangat membantu mereka dalam menjalankan tugas memproses siswa tersebut menjadi lulusan yang bermutu tinggi.

Pemahaman tentang pengelolaan personel akan membantu upaya pengembangan pribadi dan profesionalnya, pemahaman pengelolaan prasarana dan sarana membantu memperluas wawasan tentang bagaimana ia dapat berperan dalam merencanakan, menggunakan, mengevaluasi prasarana dan sarana yang ada sehingga prasarana dan sarana yang tersebut dapat dimanfaatkan dengan optimal,pemahaman tentang seluk beluk administrasi keuangan membantu guru dalam menetapkan prioritas pelaksanaan tugasnya karena pada akhirnya dana untuk menunjang kegiatan nya juga terbatas,pemahaman tentang hubungan sekolah dan masyarakat akan membantu guru dalam usaha mereka menjadikan sekolah bagian yang tidak terpisahkan dari masyarakat,sehingga terjalin kerjasama yang baik diantarakeduanya.

Administrasi prasarana dan sarana pendidikan merupakan keseluruhan proses pengadaan, pendayagunaan, dan pengawasan prasarana dan peralatan yang digunakan untuk menunjang pendidikan yang telah ditetapkan tercapai secara efektif dan efisien.Sebagai pelaksana tugas pendidikan,guru juga mempunyai andil dalam administrasi prasarana dan sarana pendidikan dalam hal ini guru lebih banyak berhubungan dengan sarana pengajaran,yaitu alat pelajaran,alat peraga dan media pengajaran lainnya.

Kebijakan pemerintah tentang pengelolaan sarana dan prasarana sekolah tertuang di dalam UU No. 20 tahun 2003 tentang Sisdiknas pasal 45 ayat (1) yaitu "setiap satuan pendidikan formal dan nonformal menyediakan sarana dan prasarana yang memenuhi keperluan pendidikan sesuai dengan pertumbuhan dan perkembangan potensi fisik, kecerdasan intelektual, sosial, emosional dan kejiwaan peserta didik."

Peranan guru dalam administrasi prasarana dan sarana dimulai dari perencanaan,pemanfaatan dan pemeliharaan, serta pengawasan penggunaan prasarana dan sarana yang dimaksud :

1. Perencanaan

Perencanaan pengadaan barang menuntut keterlibatan guru karena semua barang yang dipergunakan dalam proses belajar mengajar harus sesuai dengan rancangan kegiatan belajar mengajar itu. perencanaan pengadaan barang yang menuntut keterlibatan guru diantaranya adalah pengadaan alat pengajaran dan media pengajaran.

2. Pemanfaatan dan pemeliharaan
Guru harus dapat memanfaatkan segala sarana seoptimal mugkin dan bertanggung jawab penuh terhadap keselamatan pemakaian sarana dan prasarana pengajaran yang ada.

3. Pengawasan penggunaan

Apabila sarana dan prasarana pendidikan itu digunakan oleh siswa yang ada dikelasnya, maka tugas guru adalah melakukan pengawasan atau memberikan arahan agar siswa dapat menggunakanatau memakai sarana dan prasarana pendidikanitu sebagaimana mestinya.

\section{KESIMPULAN}

Administrasi prasarana dan sarana pendidikan merupakan keseluruhan proses pengadaan, pendayagunaan, dan pengawasan prasarana dan peralatan yang digunakan untuk menunjang pendidikan yang telah ditetapkan tercapai secara efektif dan efisien.Sebagai pelaksana tugas pendidikan,guru juga mempunyai andil dalam administrasi prasarana dan sarana pendidikan dalam hal ini guru lebih banyak berhubungan dengan sarana pengajaran,yaitu alat pelajaran,alat peraga dan media pengajaran lainnya.

Kebijakan pemerintah tentang pengelolaan sarana dan prasarana sekolah tertuang di dalam UU No. 20 tahun 2003 tentang Sisdiknas pasal 45 ayat (1) yaitu "setiap satuan pendidikan formal dan nonformal menyediakan sarana dan prasarana yang memenuhi keperluan pendidikan sesuai dengan pertumbuhan dan perkembangan potensi fisik, kecerdasan intelektual, sosial, emosional dan kejiwaan peserta didik". Peranan guru dalam administrasi prasarana dan sarana dimulai dari perencanaan,pemanfaatan dan pemeliharaan, serta pengawasan penggunaan prasarana dan sarana yang dimaksud :Perencanaan, Pemanfaatan dan pemeliharaan, Pengawasan penggunaan

\section{Daftar Pustaka}

Afriansyah, Hade. 2019. Artikel Konsep Dasar, Proses, dan Ruang lingkup Administrasi Pendidikan. Padang. https://mfr.osf.io/render?url=https://osf.io/emzvn/?direct $\% 26$ mode $=$ render $\% 26$ action $=$ download $\% 26$ mode $=$ rende $\underline{\mathrm{r}}$

Daryanto. 2008. Administrasi Pendidikan. Jakarta: Rineka Cipta.

Gunawan, Ary H, Administrasi Sekolah: Administrasi Pendidikan Mikro, Jakarta: Rineka Cipta, 1996.

Sabri, Ahmad. 2000. Administrasi pendidika.Padang: IAIN IB PRESS

Soetjipto \& Raflis kosasi.2003.Profesi Keguruan.Jakarta:Rineka cipta 